\title{
What Works at Work? Towards an Integrative Model Examining Workplace Campaign Strategies
}

\author{
Genevieve G. Shaker, gshaker@iupui.edu \\ Indiana University-Purdue University Indianapolis \\ Robert K. Christensen, rc@byu.edu \\ Brigham Young University \\ Jonathan Bergdoll, jibergdo@iupui.edu \\ Indiana University-Purdue University Indianapolis
}

3-1-2017

Abstract

Many United States employees are regularly asked to give charitable donations through work. The techniques used to solicit workplace donations vary. Drawing on a nationally representative survey, the study used a sample of donor responses to examine the effectiveness of several widely used campaign strategies-donor choice, company matching, public recognition, and solicitation support. The theoretical framework built on workplace research by Barman (2007) and established charitable giving mechanisms (Bekkers and Wiepking 2011a, 2011b). The research question was, Do workplace campaign strategies lead employees to participate and to make (larger) donations in the workplace? The positive outcomes of the strategies, aside from donor choice, were limited, suggesting that "tried and true” workplace fundraising strategies warrant additional scrutiny. The findings are meaningful to campaign managers seeking to identify approaches that generate workplace giving. For researchers, the results confirm growing attention to the importance of purpose-based giving in comparison with community-based giving.

This is the author's manuscript of the article published in final edited form as:

Shaker, G.G., Christensen, R.K., \& Bergdoll, J.J. (2017). What Works at Work? Toward an Integrative Model Examining Workplace Campaign Strategies. Nonprofit Management and Leadership, 28(1), 25-46. https://doi.org/10.1002/nml.21270 


\section{Introduction}

The workplace is a social environment in which employees are asked to behave philanthropically . Under the umbrella of “workplace giving,” employees make donations—with employer endorsement, often in the form of a campaign — for charitable purposes. Workplace giving campaigns, organized efforts which provide employees with tools to facilitate philanthropy, are a regular part of occupational life across all sectors domestically and abroad (Barman 2006; Haski-Leventhal 2013).

Partly due to the variety of workplace giving methods within an even more diverse system of organizations, documentation of workplace giving is somewhat limited. Workplace donations are thought to be sizeable, but the most recent national analysis of how sizeable took place when Giving USA (2007) reported a workplace total of \$4.2 billion. The United Way alone now raises approximately $\$ 3.5-\$ 4.0$ billion annually (Hrywna 2015).

Workplace giving may be at a turning point, making it more important to understand employee responses to workplace campaigning. Many in the United States work part-time and on a contractual basis, possibly influencing workers’ desire to participate in employer-led philanthropic efforts. Moreover, convenient tools now allow individuals to “emulate” payroll giving through automatic deductions from bank accounts and credit cards. Ample online platforms provide venues to deploy one's own fundraising campaign and to participate in others' private initiatives (for example, Donorschoose.org and Fundly.org) and technology now makes it eaiser for for smaller companies to participate in formal workplace campaigns. The newest generation of workers (millennials) is expressing strong interest in workplace giving participation (The Millennial Impact Project 2015). If organizations hope to continue to receive 
substantial gifts through the workplace, it is imperative to understand what "works" in the workplace.

Drawing on a nationally representative survey, this study relied on a sample of donor responses to several widely used campaign strategies_-donor choice, company matching, public recognition, and solicitation support. The theoretical framework built on workplace research by Barman (2007) and literature about charitable giving mechanisms (Bekkers and Wiepking 2011a, 2011b). The research question was, Do workplace campaign strategies lead employees to participate and to make (larger) donations in the workplace? While the existing, limited literature on workplace giving includes some assessment of campaign strategies—typically focused on a single organization or industry—-we based our empirical analyses of these factors on a national survey and contextualize the findings with theory.

\section{Contextualizing Workplace Strategies: An Integrative Model}

Scholars provide several multilevel framing approaches to organize the myriad dynamics of philanthropic giving (Bekkers and Wiepking 2011a) and workplace giving (Barman 2007; Nesbit, Christensen, and Gossett 2012). The Bekkers and Wiepking meta-analysis names eight mechanisms that influence philanthropic giving: awareness of need, altruism, values, solicitation, reputation, efficacy, costs and benefits, and psychological benefits. Locus matters and Bekkers and Wiepking categorize the mechanisms to be within, between, or outside potential donors. Workplace and federated giving scholars similarly identify micro, meso/dyadic, and macro dynamics (Barman 2007; Nesbit et al. 2012). We draw upon the similarities of within-micro, between-meso, and outside-macro to position workplace campaigning in broader notions of giving (see Figure 1).

Micro/Within Dynamics 
The microlevel perspective focuses within an individual, and specifically on characteristics and traits—-for example, demographic attributes that may correlate with philanthropic giving behavior (Barman 2007). Age is typically significant in giving, but workplace results are mixed, with only select studies finding significance (Agypt, Christensen, and Nesbit 2012; Bekkers and Wiepking 2011b; Borden, Shaker, and Kienker 2014; HaskiLevanthal 2013; Osili, Hirt, and Raghavan 2011). A higher level of education is generally positively correlated to U.S. philanthropic giving (Bekkers and Wiepking 2011b), but Osili and colleagues (2011) found workplace donors to be less likely to have bachelor's degrees than nonworkplace donors. Findings on gender in philanthropic giving are mixed (Bekkers and Wiepking 2011a). One workplace study found that women were more likely to participate than men (Carman 2004). Other workplace giving studies found race/ethnicity to be significant (Borden et al. 2014; Knight 2004), not necessarily in alignment with the general US giving. For example, Knight’s (2004) university-based study noted that Black employees were more likely to donate than Caucasian employees. A higher level of religious involvement is another common correlate to philanthropic giving, but most workplace giving studies lack the data to address this characteristic. One university-based study, however, didn’t find religious involvement to be significant (Nesbit et al. 2012) while a larger national study (Osili et al. 2011) determined that workplace donors attend religious service more frequently.

This discussion of micro-within dynamics indicates, first, little consensus in the workplace regarding even commonly studied characteristics of philanthropic givers, and second, that workplace giving may vary in several regards from nonworkplace giving, perhaps because of a mediating effect from the workplace environment (Shaker et al. 2014).

Meso/Dyadic/Between Dynamics 
Meso- or dyadic-level dynamics focus on the exchange and relationships between the employer and the employee. Explorations of the "relational” or between-based aspect of individual and organizational interaction found length of service and salary (mirroring findings about household income) to be positively correlated with giving propensity. Likewise, position type was often significant, though not always in the same way (Agypt et al. 2012; Bekkers and Wiepking 2007; Borden et al. 2014; Knight 2004; Romney-Alexander 2001; Shaker et al. 2014). Moving up the multilevel continuum, mesolevel, or dyadic ties include the reciprocity between donors and nonprofits—including organizations' solicitation approaches and related donor experiences (Barman 2007; Nesbit et al. 2012). One can argue that the employer is an intervening or mesolevel actor that "translates” the nonprofits' charitable requests for employees and determines how the giving campaign will function. The organizational context where the campaign "host" company is, is likely an "actor" that constrains the campaign.

The nature of the workplace and the campaign may therefore be relevant in campaign success. For example, Osili and colleagues (2011) discovered that workplace giving incidence increased as the company/organization size increased and that certain industries (for example, finance) had higher participation rates. Another perspective comes from literature regarding intraorganizational workplace campaigning. Shaker (2013), examining how universities raise money from employees, found that smaller institutions tended toward higher rates of participation but more modest individual gift amounts. Shaker and colleagues' (2014) higher education congruent case study determined that campaign deployment did not necessarily lead to better rates of participation or higher giving levels.

\section{Macro/Outside Dynamics}


Barman’s (2007) work proposes that neither the microlevel nor the meso/dyadic ties perspectives fully articulate the environment in which a gift is requested and a gift is given. Barman joins Bekkers and Wiepking (2011a) in suggesting that outside mechanisms are important and that scholars should consider the organizational or community environment. This macrolevel perspective posits that organizations and donors are embedded in a contextual setting that can constrain (and facilitate) their actions. The workplace provides a perspective to consider how a particular actor/entity (in this case, the employer) and the correlated campaign strategies may relate to giving. The workplace is a lens for exploring the environmental consequences in a bounded setting. One prominent example is Barman's (2007) research documenting the social shift from communities of place (for example, United Way giving) to communities of purpose (for example, donor choice models) for workplace giving.

Some scholarly analysis arguably spans the micro-, meso-, macrocontinuum. A few studies address aspects of social role, mobilization context, social exchange, and organizational identification and commitment (Agypt et al. 2012; Borden et al. 2014). However, these lack specific attention to the complexity of campaign deployment with organizational strategies and sanctions. An increasing number of scholars discuss individual- or microlevel attributes that drive workplace giving—most drawing on the interest in (and availability of data about) individual-level drivers of philanthropy. Again, some scholarship focuses on macrolevel drivers of giving (see Barman 2007) and some uses meso/dyadic attributes (Nesbit et al. 2012). Our purpose is to contextualize and analyze campaign strategies and recognize that these largely reflect meso/dyadic-level dynamics. In Figure 1, a visualization places these strategies primarily at the meso/dyadic level to reflect the employee's relationship to their workplace. The model recognizes, however, overlap with other levels. Donor choice, for example, facilitates several of 
the community (macro) attributes documented by Barman’s (2007) notions about shifting social norms in giving.

\section{- FIGURE 1 -}

\section{Workplace Campaign Strategy Literature}

The following subsections review the literature about the four campaign strategies of interest and establish the study hypotheses.

\section{Donor Choice}

Donors prefer to be able to direct charitable funds to their chosen purposes and organizations (Bennett 2003). Workplace donor choice, which enables employee discretion in choosing the object(s) of their charitable gifts, is increasingly common. A campaign strategy that focuses on donor choice energizes macro- and meso/dyadic-based giving dynamics (see Figure 1). By offering increased choices, the employer facilitates broader social preferences for purpose-based giving and, specifically, facilitates more favorable meso/dyadic employeeemployer relationships by accommodating employee preferences.

As recently as the 1990s only 10 percent of United Ways made choice available in their campaigns (Barman 2008). Qualitative (Byrne 2005; Knight 2004) and quantitative research (Haski-Leventhal 2013; Lund 1998; Romney-Alexander 2002) now discuss donor choice as a motivating determinant of workplace giving. One study focused on University of Washington's and Washington State’s Combined Federal Campaigns (Krishnamurthy 2002). When the campaign added more charities, contributions increased without dimishing support for the original organizations. A survey of fundraising personnel $(\mathrm{N}=164)$ showed a pattern among university faculty who prioritized restricted gifts to academics and scholarships—-suggesting choice was preferred (March 2005). Barman (2007) found that purpose-based giving was 
increasingly attractive compared to place-based giving, implying that donors preferred to select from a range of charitable purposes. Another study by Barman (2008) of United Way organizations $(N=337)$ concluded that younger and more-educated populations expected greater availability of donor choice, suggesting a generational and educational trajectory. Shaker (2013) discovered that university faculty who were major donors gave almost exclusively for specialized purposes, again implying the value of donor choice. The recent evidence suggests that workplace donor choice is overwhelmingly popular and an expected option.

Hypothesis 1: Offering employees a choice of charitable beneficiaries will increase gift amounts in the workplace.

\section{Company Matching}

Incentivizing a gift from one individual or entity with a gift from another (a match) is a common fundraising tactic (Sanders, Smith, and Norton 2013). The premise is that the prospective donor will give or give more because their gift will be magnified. In our model (see Figure 1), matching strategies are viewed as examples of meso/dyadic-level dynamics. Employers and campaign managers seek to influence employees' donative behavior through matching.

Evidence shows that a match significantly affects donating and donation amounts (Karlan, List, and Shafir 2011). In one example, donors liked to generate matching support for charity; however, increases in the match ratio only minimally affected donations (Eckel and Grossman 2008). A consequence of matching programs may be that donors give less because they count the match contribution as a replacement for their own gift (see Meier 2007). Sanders and colleagues (2013) hypothesized that matches may be more relevant to those who give at higher levels. The magnitude of the match, the purpose of the donation, and the request timing might also be relevant. 
A policy of company matching donations - that is, when organizational donations/funds are offered as an incentive for employee donations—-was the most important self-reported reason for giving among high-level (71 percent) and low-level donors (61 percent; albeit only minimally statistically significant) in one large Australian study (Haski-Leventhal 2013). It follows that donors and nondonors may respond differently to matching offers. In Shaker’s (2013) qualitative study of major university donors, the respondents valued the availability of a match, noting an effect on gift timing, size, and nature. In another study, alumni of a business school reported that employer matching of their charitable contributions could influence their gift size (Okunade and Berl 1997). Likewise, millennials and their managers self-reported a higher likelihood of participation if their gifts were matched (The Millennial Impact Project 2015). Noting the particular relationship between employees and employers, employees may especially appreciate the ability to direct company matching funds to their chosen charitable purpose.

Hypothesis 2: A policy of companies’ matching employee gifts will relate positively to the likelihood of giving and the gift amount in the workplace.

\section{Public Recognition}

Giving campaigns often allow public donor identification (Andreoni and Petrie 2004). Publicity may relate to giving decisions (either positively or negatively), as may other social pressures (Silverman, Robertson, Middlebrook, and Drabman 1984; Smith and McSweeny 2007). Our model (see Figure 1) incorporates public recognition strategies as examples of meso/dyadic-level dynamics where employers/campaign managers seek to influence employee giving by facilitating recognition opportunities.

A few workplace studies assess the relative value of public recognition-that is, the publicizing donor names within the organization —-though they tend to be qualitative, limited in scope, or both. Within the university context where the gifts were for internal needs, descriptive 
studies of campaigns (Byrne 2005; Cardon 2009; Gray and Hohnstreiter 2012) emphasized various forms of recognition, from celebratory events to attention for participating units, as an impetus for giving. In other cases, the purpose for recognition was broader and discussed in organizational terms as, for example, an avenue for encouraging other potential donors (Knight 2004; Shaker 2013). Millennial workplace donors, meanwhile, reported an interest in public recognition and incentives, such as competitions (The Millennial Impact Project 2015). Positive responses to public recognition most often centered upon group experiences associated with giving.

A Chinese study directly examined the roles of public recognition and associated pressures on workplace giving (Du, Zhao, and Zhang 2014). This research indicated that donating was (in some situations) "rarely voluntary," and indeed obligatory. Pressure in the form of releasing lists of donors and donation amounts was negatively correlated with intentions to donate; the research did not examine the effect on donation amounts. This "flip side" of public recognition—when employees wanted to publicize their participation for fear of negative consequences—-has parallels within the American workplace. Nesbit and colleagues’ (2012) university-based study reported that some individuals said that they donated as a form of selfdefense. Individual-level, public recognition, rather than group-centered recognition, generally garnered a negative response in the workplace research.

In this study, public recognition is derived from self-reported data; how important is public recognition to the respondent's workplace giving? Extending the literature, we predict that the role of public recognition might actually be negatively related to workplace giving.

Hypothesis 3: The role of public recognition as a motivation for giving within the workplace will negatively relate to likelihood of giving and gift amount.

Solicitation Support 
Demonstrating giving through public recognition may be intertwined with donors’ responses to gift solicitation. "Solicitation"- or the very act of being asked to give and how one is asked—is an integral to the giving decision (Bekkers and Wiepking 2011a). An example of a meso/dyadic-level dynamic is where employers, campaign managers, or peers seek to influence employee giving behavior by leveraging different means of solicitation.

Lund's (1998) survey of United Way participants indicated a positive perception of volunteer leaders among those who contributed to the campaign. Likewise, use of "departmental representatives" was deemed a good strategy by the donor majority in a small qualitative portion of a larger university-based study (Knight 2004). In 2015’s The Millennial Impact Project tudy, the millennial participants reported that both supervisors and coworkers influenced their giving, although coworkers more substantially so. March (2005), in a study of higher education fundraisers, discovered a perception that participation was most likely with solicitation by campaign supporters—-peers, department chairs, the campaign chair—or by the university president. In the Chinese context, Du and colleagues (2014) noted that campaigns organized by peers rather than supervisors resulted in a higher intention to participate (and a perception of a lower degree of pressure). In a mail survey to over 200 faculty donors, "peer pressure" was one of the lowest rated forms of motivation (Holland 1997). Perhaps not surprisingly, given stereotypes about fundraising personnel, Holland's (1997) participants said that neither phone calls nor visits from "professional fundraisers" were important in their gift decisions. When donors spoke about "professional fundraisers" and "peer pressure” versus questions framed in less leading language, differences of opinion emerged, explaining to some degree variation between study findings. In the present analysis, a question asked whether solicitation by an 
employer or by a friend/associate were major motivators, minor motivators, or nonmotivators. In that context we hypothesized positive outcomes.

Hypothesis 4: Solitication by the employer or a friend/associate will positively relate to likelihood of giving and gift amount in the workplace.

\section{Methodology}

The existing research provides important, if limited, insights from which we sought to develop an understanding of workplace giving characteristics within the campaign context. We hoped to advance both scholars’ and practitioners’ understanding of campaign strategy effectiveness in relation to donor choice, company matching, public recognition, and solicitation support.

\section{Data}

The data were drawn from a nationally representative survey on workplace giving administered in late 2008 by Knowledge Networks, a survey company that maintains a nationally representative panel. The survey was given to currently employed, full-time workers ages twenty-five and above and had a response rate of 71 percent. While the full sample was approximately 6,000 respondents, our analysis focused on those whose workplaces offered giving. This sample was 1,858 respondents. Respondents were asked about the presence of a workplace campaign, whether and how much they donated in the previous twelve months, and about select characteristics of their workplace campaign. The questionnaire included items about nonworkplace giving in the format of the Philanthropy Panel Study (see Panel Study of Income Dynamics [PSID] 2016). While some years old, the data are a source for other research (Osili et al. 2011) and offer insights into US workplace giving habits not available elsewhere.

\section{Measures}


Our dependent variable of interest was employee giving to their workplace campaigns. We examined incidence of giving and logged amounts of giving through the workplace using questions asked directly of the respondents (see Appendix A). ${ }^{1}$ Respondents were asked if they had donated (separate questions for workplace and nonworkplace) and, if they had, how much. For the ordinary least squares (OLS) analysis, the gift amount was put into logarithmic form, a common transformation used to help limit any undue influence of outlier values.

We conditioned the analyses on whether the respondent reported availability of a workplace giving campaign of any sort for continuity (between workplace or nonworkplace giving). For our independent variables of interest, we included whether the campaign offered observed opportunities to aid in and/or incentivize giving. These included donor choice and donor matching. The donor choice question was asked only of respondents who reported giving through the workplace and could not be used to test incidence. We included additional variables for possible influences: whether the employer or a coworker requesting gifts would be a motivating factor in the giving decision, and whether public recognition for giving influenced the respondents. For robustness, we completed several analyses split by gender, age (see Appendix B), and industry of employment (Appendix C and Appendix D).

The industry splits are presented in the appendix as a sample of the differences that emerged. These analyses recognize that giving strategies like donor choice and matching may not be randomly distributed across companies/industries nor equally influential across key demographics like age and gender, suggesting a study limitation.

\footnotetext{
${ }^{1}$ In some instances we also examined incidence of nonworkplace giving for comparison and context.
} 
For hypothesis 1, the question examining thedonor choice was, “Did you have the option to direct all or a portion of your workplace campaign donation to a specific nonprofit organization or cause in the past twelve months?”

For hypothesis 2, the question examining the availability of employer matching began, “To your knowledge, what types of charitable giving is your employer involved in?” and offered "Matching employee donations to charities” as one choice. These first two questions were asked in a yes/no format.

For hypothesis 3, the question examining public recognition began, “When you make donations to a workplace campaign, how important is it to you that the workplace campaign organization ... ” One of the provided options was "Give public recognition for my donation.” The format of the question asked respondents to indicate whether this was very unimportant, somewhat unimportant, neutral, somewhat important, or very important.

For hypothesis 4, the question examining solicitation support began, "Indicate whether the following is a major motivation, minor motivation, or no motivation at all when you give to nonprofit organizations:” and included among the subheads: "Being asked by your employer” and "Being asked by a friend or associate," which were used in this analysis. Respondents were asked whether each was a major reason, minor reason, or no reason. To be clear, the question and response options assumed that respondents had had this experience and could cite it as a major reason, minor reason, or no reason.

For the analysis, we operationalized all the questions as binary variables, though nonbinary variants were tested for robustness with no significant differences in the results. Fordetail, including coding/recoding, please see Appendix A.

\section{Analysis and Results}


Table 1 presents descriptive information about the study sample. The percentage of people who reported charitable gifts is higher than that shown in other surveys, such as the Philanthropy Panel Study, which reported a 64.2 percent incidence of giving during roughly the same time period (PSID 2016). We attribute this to the inclusion of only employed individuals, a population that tends to give more frequently than the unemployed (PSID 2016).

\section{-- TABLE 1 --}

Separate analyses, probit and OLS regressions, were elected over a single tobit because the donor choice variable was asked only of those who reported giving through the workplace. The methods also underscore the two-part nature of giving: the decision to give (probit) and, if affirmative, how much to give (OLS). For all regression models, the weights included with the survey data were used.

While OLS is typically the standard analysis, a basic binary (yes/no) analysis, like probit, was useful in this study because different factors may influence the decision to give in comparison with decision of how much to give. Importantly, these influences do not necessarily operate in the same direction. If a factor induces a small gift from someone who otherwise would not donate, this factor could present as positive in the probit but negative in the OLS. If only one of these analyses were completed, this effect may not have been captured. Our standard controls included microlevel factors: age, income, education, and gender, which are discussed in the next section.

\section{Microlevel, Demographic Results}

We began with the probit analyses for context, examining factors that shaped whether the employees gave (Table 2, probit marginal effects reported). Educational level is not significant in participation in workplace giving, though it is externally. Respondents making $\$ 100,000$ - 
$\$ 149,000$ (omitted category is below $\$ 50,000$ ) were more likely to give at work and outside of work. Age was significant in both contexts and gender was not significant in either. In the OLS analyses, in the workplace, being better paid and more highly educated were positive and significantly correlated with larger gifts (Table 3). Age was also significant in gift amounts while gender was not.

-- TABLE 2 --

-- TABLE 3 --

Meso/dyadic-level and Macrolevel Results

We examined the meso/dyadic-level (donor choice, matching, recognition, solicitation support) and macrolevel (donor choice) dynamics.

\section{Hypothesis 1: Donor Choice}

As predicted, donor choice was positively correlated with the amount given through the workplace (Table 3). This finding confirmed our first hypothesis. Holding all other variables constant, the presence of donor choice increased workplace donations by $\$ 58$ for those already donating through the workplace. ${ }^{2}$ Indeed, donor choice emerged as the key driver for gift amounts.

\section{Hypothesis 2: Company Matching}

The presence of company matching donations was found to be positive and significant on its own in giving incidence and amount (Tables 2 and 3). Holding all other variables constant, the presence of company matching increased the incidence of workplace giving by almost 8 percent. This suggested some support for our second hypothesis. However, when considered with a donor choice dummy variable (available only for the OLS model and presented in Table 3), company

2 The value is the difference between two expected values, calculated from the regression results while holding all other variables at means. This calculation is reproduced for all significant findings. 
matching had only a slightly positive effect on the gift amount, which was not statistically significant.

\section{Hypothesis 3: Public Recognition}

The employee's response to public recognition had a nonsignificant but negative effect on giving in the workplace in incidence and amount (Tables 2 and 3). We draw from this little conclusive support for the hypothesis. The preference for public recognition may have been considered a socially undesirable response, perhaps leading respondents to view recognition negatively and to be less likely to respond positively. This may have led to an underestimation of recognition's effects.

Related to this, we also recognize that our nonfindings may be attributed to the limitations of the available data to more precisely differentiate between (1) how important respondents' self-reported preference was for public recognition for their donation and (2) how bestowed public recognition actually influences workplace giving. The preferential versus observational distinction is a potentially important one that deserves future attention.

\section{Hypothesis 4: Solicitation Support}

We examined campaign “asks” by using two variables that allowed the respondent to list encouragement from either (1) the employer or (2) an associate or friend as a motivating factor in the gift decision. We called these solicitation support variables. The employer solicitiation support variable held a strong positive significance for whether an individual donated (a 9.1

percent increase; Table 2). It had a negative (though nonsignificant) effect on the amount donated (Table 3). Being asked by a friend/associate did not motivate workplace participation and had a significant negative effect on gift amount. This signaled mostly negative, though inconclusive, findings for the fourth hypothesis. Employer encouragement may have moved 
neutral individuals to donate, but these individuals did not seem to donate as much as those who did not need encouragement to give. Meanwhile, peer influence did not have the desired effects. Workplace relationships, therefore, were connected to donations in a complex manner.

\section{Discussion}

Bekkers and Wiepking's (2011a) review of philanthropic mechanisms suggests that locus matters. They propose that giving mechanisms can be categorized as within, outside, or between potential donors. Past workplace and federated giving scholars have offered similar, parallel logic in noting micro-, meso/dyadic, and macrodynamics that influence workplace giving (Barman 2007; Nesbit et al. 2012). Much of the workplace research, indeed much of the general philanthropy research, has largely focused on the "within” mechanisms. In one workplace study, microlevel or "within" individual conditions were found to be more relevant than the presence of a campaign (a mesolevel construction intended to encourage donations) in predicting giving (Shaker et al. 2014). Our research engaged specific meso/dyadic-level campaign strategies to assist researchers and practitioners with the dynamics of workplace giving within the broad framework of philanthropic understanding.

The first hypothesis explored how a strategy of donor choice related to the gift amount. Donor choice positively related to the extent of giving, demonstrating the promise of combined macro- and meso/dyadic-based campaign strategies.

Tying our research to extant literature, donor choice is a strategy that may best reflect an “awareness of need” mechanism (Bekkers and Wiepking 2011a). Barman’s (2006) work evidenced shifting social understanding of needs as donors increasingly prioritized purposebased giving over place-based giving. Our nationwide study largely compliments Barman’s sitespecific work about San Francisco and Chicago. A strategy of offering donor choice reflects an 
accommodation of shifting preferences towards purpose-based giving and, therefore, could explain its strong effect on campaign giving. Donor choice (and promotion of its availability) appears to be an effective tool for increasing workplace donation amounts.

The second hypothesis examined the relationship between company matching and workplace giving. We found that company matching may be related to an individual's decision to give at work, but company matching has little positive impact on the amount given. This may be particularly true when other strategies are present. In other words, when tested alongside donor choice, matching lost its significance in giving amount. Future research is needed to better distinguish competing/substitution effects of strategies upon one another.

General philanthropic mechanisms like "efficacy" — that is, the total magnitude of the gift that can be amplified through employer matching—and “costs” (Bekkers and Wiepking 2011a) may be slightly less important in the workplace giving context. Perhaps the ability to make gifts through payroll deduction, removing them before compensation is received, eases the burden of the fiscal "cost" of workplace philanthropy. One could also conjecture that the presence of a mediating body, such as the employer and/or a workplace giving federation, might reduce worker concerns regarding efficacy. Ultimately, this finding may limit the impact of meso/dyadic-level driven workplace tactics.

The third hypothesis centered on the effect of an employee's preference for public recognition as a motivation for giving in the workplace. We found no significant relationship between workplace giving and a self-reported preference for public recognition.

The fourth hypothesis explored how campaign solicitation support related to workplace giving. We measured this by examining how the employers' encouragement motivated the incidence and extent of giving. We found the perception of solicitation support from employers 
to be significantly positive in giving likelihood but (nonsignificantly) negative in workplace gift amounts . Peer asks were not a motivating factor in giving decisions. Perhaps then, employer encouragement is a good strategy for participation goals but less so for reaching fiscal goals within campaigns. The question of how best to support a campaign "solicitation” strategy/mechanism with coworker volunteers is nuanced and heavily overshadowed by considerations of relational workplace dynamics (Bekkers and Wiepking 2011a). The meso/dyadic-level campaign strategy was of some, but limited, benefit in this case.

This study has limitations. First, the data were cross-sectional and self-reported. The former condition limits our ability to make statements about causality and the latter prevents us from ruling out the possibility of same-source bias. Second, while we examined four major campaign strategies, this was certainly not an exhaustive list. Further, while we examined donor choice in relation to giving amount, due to survey construction we could not examine the role of donor choice in whether someone gave at work. Finally, no explicit measures of fully macrolevel variables appeared to influence workplace giving. This indicates the possibility of at least one source of omitted variable bias. We recommend Barman’s (2007) research to those with particular interests at the macrolevel but must rely on future analyses to fully incorporate micro-, meso/dyadic-, and macrolevel variables.

\section{Conclusion}

The purpose of this paper was to contextualize and integrate workplace campaign strategies within a broader model of giving. We also sought to provide empirical evidence regarding the effectiveness of several campaign strategies: donor choice, donor matching, public recognition, and solicitation support. We largely conceptualized these strategies as meso/dyadiclevel dynamics (see Barman 2007; Nesbit et al. 2012). We relied on the literature to develop 
hypotheses. Using a representative, national sample of workers, we tested these hypotheses in models that also included microlevel demographic controls. The results are summarized in an expanded Figure 2, which illustrates how we conceptualized and operationalized workplace giving strategies as well as the microlevel individual controls.

- FIGURE 2 -

The analysis leads to the conclusion that, after controlling for microlevel dynamics like individual demographics, meso/dydadic-level campaign approaches matter in varying degrees. We identified donor choice as a key strategy to encourage giving in the workplace. The importance of gift matching is less clear. Additionally, public recognition is an area in which to tread lightly given inconclusive findings. Finally, experimenting with campaign solicitors can be a tricky proposition.

When thinking about "next-generation" employee donors, evidence suggests that our findings may not hold. For example, many of our results did not align with survey information that highlighted millennial perspectives on workplace giving (Achieve 2015). This supports the value of a deeper investigation of workplace behavioral data around questions of age and responsibility in order to generate more multifaceted findings.

In the context of Bekkers and Wiepking’s (2011a) mechanisms, “awareness of need” (donor choice) and "solicitation” (solicitation support) stand out as prime candidates for attention in the workplace. Many of the same general philanthropic mechanisms are present in the workplace. Yet, future research is needed to determine just how different (or similar) workplace motivators are to nonworkplace factors. Research could enhance campaign planning and anticipate changes in employee responses to workplace solicitation given shifts in technology, worker-employer relations, and social norms. Ensuing research begs for refinement and testing 
through application and experimentation. Few workplace-specific studies quantifiably examine employee responses to specific campaign strategies. This study was an early step in this direction. Opportunity is ample for further empirical and generalizable approaches to examining campaign tactics.

Future researchers would be wise to explore the kinds of choices employees want and how those choices should be presented. Workplace trends are moving well ahead with a growing range of options for employees and employers. These tendencies could be leveraged based on research to make workplace giving more supportive and effective. Barman (2007) proposes that the macrolevel concerns — or context in which nonprofits and fundraisers must function—are fundamental elements that deserve attention. Potential donors experience the workplace as a "distinct area of social space, in which all the relevant actors are influenced by the overall structure” (Swedberg 2006, 6), making structural concerns highly pertinent. There appears to be an industry-specific component (see Appendix B and C), leaving open the possibility that certain industries (or sectors) are more or less likely to attract those interested in workplace giving and to encourage community involvement/support—a notion that has been explored in relation to volunteerism and employees (Ariza-Montes, Roldán-Salgueiro, and Leal-Rodríguez 2015; Lee and Brudney 2015)—or are possibly more likely to implement specific strategies. In the future, workplace fundraising campaign implementation and testing will be valuable for determining site-specific determinants of philanthropic behavior. Dicerning what works at work is a fertile arena for continued philanthropic research. 


\section{References}

Agypt, B., R. K. Christensen, and R. Nesbit. 2012. “A Tale of Two Charitable Campaigns: Longitudinal Analysis of Employee Giving at a Public University.” Nonprofit and Voluntary Sector Quarterly 41 (5): 802-25.

Andreoni, J., and R. Petrie. 2004. "Public Goods Experiments without Confidentiality: A Glimpse into Fund-Raising.” Journal of Public Economics 88:1605-23.

Ariza-Montes, A., J. L. Roldán-Salgueiro, and A. Leal-Rodríguez. 2015. “Employee and Volunteer: An Unlikely Cocktail?” Nonprofit Management and Leadership 25 (3): 25568.

Barman, E. 2006. Contesting Communities: The Transformation of Workplace Charity. Stanford, CA: Stanford University Press.

Barman, E. 2007. “An Institutional Approach to Donor Control: From Dyadic Ties to a Fieldlevel Analysis.” American Journal of Sociology 112 (5): 1416-57.

Barman, E. 2008. “With Strings Attached: Nonprofits and the Adoption of Donor Choice.” Nonprofit and Voluntary Sector Quarterly 37 (1): 39-56.

Bekkers, R., and P. Wiepking. 2011a. “A Literature Review of Empirical Studies of Philanthropy: Eight Mechanisms that Drive Charitable Giving.” Nonprofit and Voluntary Sector Quarterly 40 (5): 924-73.

Bekkers, R., and Wiepking, P. 2011b. "Who Gives? A Literature Review of Predictors of Charitable Giving Part One: Religion, Education, Age and Socialisation.” Voluntary Sector Review 2 (3): 337-65.

Bennett, R. 2003. “Factors Underlying the Inclination to Donate to Particular Types of Charity.” International Journal of Nonprofit and Voluntary Sector Marketing 8 (1): 12-29. 
Borden, V. M. H., G. G. Shaker, and B. L. Kienker. 2014, “The Impact of Alumni Status on Institutional Giving by Faculty and Staff.” Research in Higher Education 55 (2): 196217.

Byrne, J. 2005. “Forming a Culture of Giving: A Case Study in Successful University Internal Fundraising.” Metropolitan Universities 16 (4): 71-84.

Cardon, R. 2009. “Developing and Implementing a Successful Employee Giving Campaign: A Case Study from Southern Utah University.” Master’s Capstone Project, Southern Utah University. http://www.suu.edu/hss/comm/masters/Capstone/Project/R_Cardon.pdf (accessed November 2, 2015)

Carman, K. G. 2004. Social Influences and the Private Provision of Public Goods: Evidence from Charitable Contributions in the Workplace. Unpublished manuscript. Stanford University, Palo Alto, CA. http://rwj.harvard.edu/scholarsmaterials/carman/SocialInfluences.pdf (accessed January 31, 2017).

Du, L., F. Zhao, and C. Zhang. 2014. “Impact of Mobilization Context on Employees’ Donation Intentions in China. Social Behavior and Personality: An international Journal 42 (1): 115-24.

Eckel, C. C., and P. J. Grossman. 2008. “Subsidizing Charitable Contributions: A Natural Field Experiment Comparing Matching and Debate Subsidies.” Experimental Economics 11 (3): 234-52.

Giving USA. 2007. Chicago, IL: Giving USA Foundation.

Gray, T., and M. Hohnstreiter. 2012. “Go for the Gold: Fundraising for Teaching Centers.” To Improve the Academy 28: 262-76. 
Haski-Leventhal, D. 2013. “Employee Engagement in CSR: The Case of Payroll Giving in Australia.” Corporate Social Responsibility and Environmental Management 20 (2): 113-28.

Holland, A. P. 1997. "Faculty Motivations for Giving to their Employing Institutions.” Dissertation Abstracts International 58 (6). UMI. 9735711.

Hrywna, M. 2015, October 6. “United Way Revenue Ticks Down.” The NonProfit Times. http://www.thenonprofittimes.com/news-articles/united-way-fundraising-up-totalrevenue-down/ (accessed October 15, 2016).

Karlan, D., J. List, and E. Shafir. 2011. “Small Matches and Charitable Giving: Evidence from a Natural Field Experiment.” Journal of Public Economics 95 (5-6): 344-50.

Knight, W. E. 2004. "Influences on Participation in a University Faculty and Staff Annual Giving Campaign.” The CASE International Journal of Educational Advancement 4 (3): 221-32.

Krishnamurthy, S. 2002. “The Washington State Combined Fund Drive: A Case Study.” International Journal of Nonprofit and Voluntary Sector Marketing 7 (1): 45-54.

Lee, Y., and J. L. Brudney. 2015. “Work-to-Society Spillover? Volunteering by Employees of Nonprofit Organizations.” Nonprofit Management and Leadership 26 (1): 105-19.

Lund, C. 1998. “Analysis of Rochester Institute of Technology’s United Way Campaign.” Master's thesis. Rochester Institute of Technology. http://scholarworks.rit.edu/theses/7387 (accessed July 1, 2016).

March, K. S. 2005. “A Descriptive Study of Faculty and Staff Giving Practices at Public Institutions of Higher Education within the United States.” Disseration Abstracts International 66 (5). UMI. 3173632. 
Meier, S. 2007. "Do Subsidies Increase Charitable Giving in the Long Run? Matching Donations in a Field Experiment.” Journal of the European Economic Association 5 (6): 1203-22.

The Millennial Impact Project. 2015. Cause, Influence \& the Next Generation: The 2015 Millennial Report. http://www.themillennialimpact.com/research/ (accessed July 1, 2016).

Nesbit, R., R. K. Christensen, and L. M. Gossett. 2012. “Charitable Giving in the Public Workplace.” Public Performance \& Management Review 35 (3): 449-74.

Okunade, A. A., and R. L. Berl. 1997. "Determinants of Charitable Giving of Business School Alumni.” Research in Higher Education 38:201-14.

Osili, U. O., D. E. Hirt, and S. Raghavan. 2011. “Charitable Giving Inside and Outside the Workplace: The Role of Individual and Firm Characteristics.” International Journal of Nonprofit and Voluntary Sector Marketing 16 (4): 393-408.

Panel Study of Income Dynamics (PSID). 2016. Public Use Dataset. Philanthropy Panel Study (PPS). Survey Research Center, Institute for Social Research, University of Michigan. http://psidonline.isr.umich.edu/ (accessed August 2, 2016).

Romney-Alexander, D. 2002. "Payroll Giving in the UK: Donor Incentives and Influences on Giving Behaviour.” International Journal of Nonprofit and Voluntary Sector Marketing 7 (1): 84-92.

Sanders, M, S. Smith, and M. I. Norton. 2013. "Non-Standard Matches and Charitable Giving." Harvard Business School Working Paper, No. 13-094, Boston, MA. http://www.hbs.edu/faculty/Publication\%20Files/13-094_0ddf9cf3-c4da-4b2e-8af439a1a7b9863e.pdf (accessed September 15, 2016). 
Shaker, G. G. 2013. “The Generosity of the Professoriate: Faculty as Donors and Academic Citizens.” Metropolitan Universities 23 (3): 5-25.

Shaker, G. G., B. L. Kienker, and V. M. H. Borden. 2014. “The Ecology of Internal Workplace Giving at Indiana University: A Case Study of Academic and Non-academic Staff Campus Campaign Fundraising.” International Journal of Nonprofit and Voluntary Sector Marketing, 19 (4): 262-76.

Silverman, W. K., S. J. Robertson, J. L. Middlebrook, and R. S. Drabman. 1984. “An Investigation of Pledging Behavior to a National Charitable Telethon.” Behavior Therapy 15:304-11.

Smith, J. R., and A. McSweeney. 2007. “Charitable Giving: The Effectiveness of a Revised Theory of Planned Behaviour Model in Predicting Donating Intentions and Behaviour.” Journal of Community \& Applied Social Psychology 17:363-86.

Swedberg, R. 2004. “The Toolkit of Economic Sociology.” SOCIUS Working Papers, No. 4. http://pascal.iseg.ulisboa.pt/ socius/publicacoes/wp/wp200604.pdf (accessed March 1, 2017). 


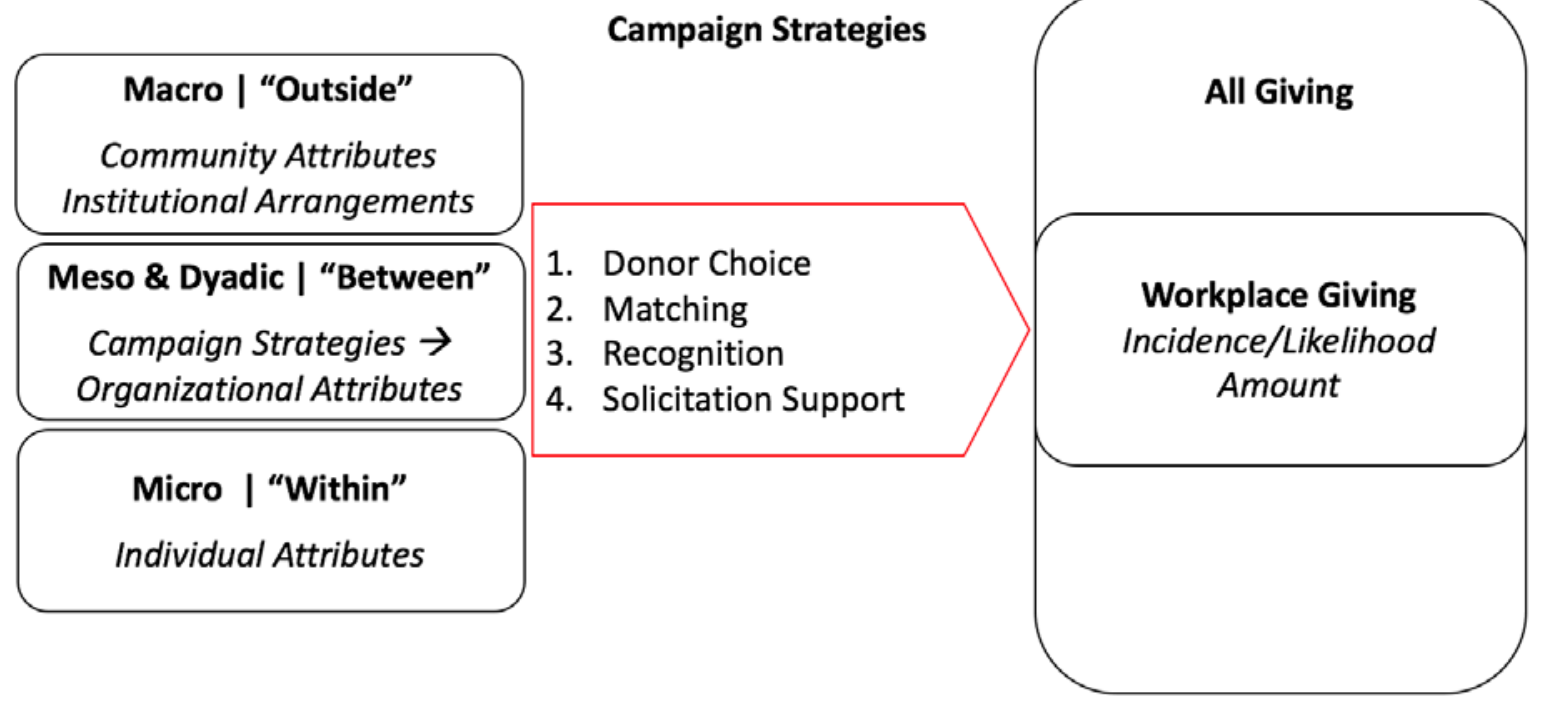

Figure 1. Integrating campaign strategies in a model of workplace giving

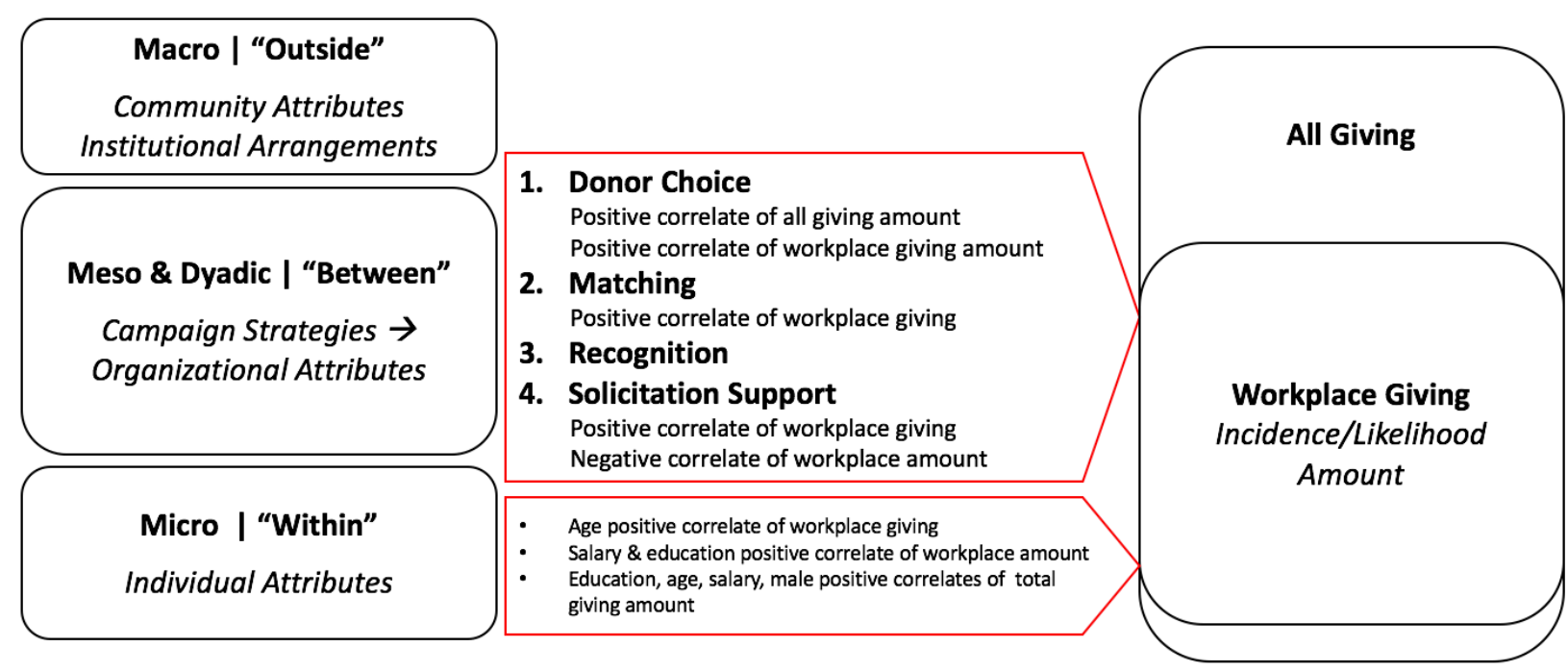

Figure 2. Findings in an integrated model of giving 
Table 1. Summary statistics of study variables (selected sample, workplace giving available only)

\begin{tabular}{|c|c|c|c|c|}
\hline VARIABLES & $\begin{array}{l}\text { Mean } \\
\text { (\% in category) }\end{array}$ & $S D$ & Min & Max \\
\hline \multicolumn{5}{|l|}{ Income } \\
\hline Up to $\$ 49,999$ & $29.8 \%$ & & 0 & 1 \\
\hline$\$ 50,000$ to $\$ 99,999$ & $47.6 \%$ & & 0 & 1 \\
\hline$\$ 100,000$ to $\$ 149,999$ & $15.4 \%$ & & 0 & 1 \\
\hline$\$ 150,000$ to $\$ 174,999$ & $3.5 \%$ & & 0 & 1 \\
\hline$\$ 175,000$ or more & $3.8 \%$ & & 0 & 1 \\
\hline Female & $50.5 \%$ & & 0 & 1 \\
\hline \multicolumn{5}{|l|}{ Age } \\
\hline $22-47$ & $59.5 \%$ & & 0 & 1 \\
\hline $48-66$ & $38.7 \%$ & & 0 & 1 \\
\hline $67+$ & $1.9 \%$ & & 0 & 1 \\
\hline Education [Bachelor's or higher] & $49.3 \%$ & & & \\
\hline Gave to charity (nonworkplace) & $86.5 \%$ & & 0 & 1 \\
\hline Gave to charity (workplace) & $64.0 \%$ & & 0 & 1 \\
\hline Donor choice is offered* & $78.4 \%$ & & 0 & 1 \\
\hline Donor matching is offered & $38.7 \%$ & & 0 & 1 \\
\hline Public recognition is important & $3.7 \%$ & & 0 & 1 \\
\hline $\begin{array}{l}\text { Solitication support: Employer asking is a } \\
\text { motivator }\end{array}$ & $49.6 \%$ & & 0 & 1 \\
\hline $\begin{array}{l}\text { Solicitation support: Friend/Associate asking } \\
\text { is a motivator }\end{array}$ & $72.3 \%$ & & 0 & 1 \\
\hline $\begin{array}{l}\text { Amount given (OLS donor-only sample; total } \\
\text { giving) }\end{array}$ & $\$ 1,340$ & $\$ 2,834$ & 1 & $\$ 41,500$ \\
\hline $\begin{array}{l}\text { Amount given (OLS donor-only sample; } \\
\text { workplace) }\end{array}$ & $\$ 227$ & $\$ 541$ & 1 & $\$ 10,000$ \\
\hline Observations & 1,858 & & & \\
\hline
\end{tabular}

* Was asked only of those who gave through the workplace 
Table 2. Demographic and campaign strategy effects on employee participation in charitable giving (probit marginal effects)

\begin{tabular}{|c|c|c|}
\hline VARIABLES & $\begin{array}{l}\text { Nonworkplace } \\
\text { Giving }\end{array}$ & Workplace Giving \\
\hline \multicolumn{3}{|l|}{ Income [Below $\$ 50,000$ omitted] } \\
\hline$\$ 50,000$ to $\$ 99,999$ & $\begin{array}{l}0.0399 \\
(0.0345)\end{array}$ & $\begin{array}{l}0.0489 \\
(0.0433)\end{array}$ \\
\hline$\$ 100,000$ to $\$ 149,999$ & $\begin{array}{l}0.140 * * * \\
(0.0312)\end{array}$ & $\begin{array}{l}0.155^{* * *} \\
(0.0498)\end{array}$ \\
\hline$\$ 150,000$ to $\$ 174,999$ & $\begin{array}{l}0.0856 \\
(0.0581)\end{array}$ & $\begin{array}{l}0.0300 \\
(0.0867)\end{array}$ \\
\hline$\$ 175,000$ and up & $\begin{array}{l}0.128 * * * \\
(0.0485)\end{array}$ & $\begin{array}{l}0.0334 \\
(0.0849)\end{array}$ \\
\hline Education [Bachelor's or higher] & $\begin{array}{l}0.0462^{*} \\
(0.0260)\end{array}$ & $\begin{array}{l}0.0407 \\
(0.0353)\end{array}$ \\
\hline \multicolumn{3}{|l|}{ Age [22-47 omitted] } \\
\hline $48-66$ & $\begin{array}{l}0.0469 * \\
(0.0241)\end{array}$ & $\begin{array}{l}0.113^{* * *} \\
(0.0330)\end{array}$ \\
\hline $67+$ & -0.0210 & 0.0315 \\
\hline Female & $\begin{array}{l}(0.0829) \\
0.0328 \\
(0.0268)\end{array}$ & $\begin{array}{l}(0.0980) \\
-0.0186 \\
(0.0345)\end{array}$ \\
\hline Donor matching is offered & $\begin{array}{l}0.0324 \\
(0.0271)\end{array}$ & $\begin{array}{l}0.0774 * * \\
(0.0353)\end{array}$ \\
\hline Public recognition is important & $\begin{array}{l}-0.0717 \\
(0.0773)\end{array}$ & $\begin{array}{l}-0.145 \\
(0.0991)\end{array}$ \\
\hline Solicitation support: Employer asking is a motivator & $\begin{array}{l}-0.0208 \\
(0.0280)\end{array}$ & $\begin{array}{l}0.0851 * * \\
(0.0360)\end{array}$ \\
\hline $\begin{array}{l}\text { Solicitation support: Friend/Associate asking is a } \\
\text { motivator }\end{array}$ & $\begin{array}{l}0.0299 \\
(0.0263)\end{array}$ & $\begin{array}{l}0.0106 \\
(0.0380)\end{array}$ \\
\hline Pseudo R-squared & 0.052 & 0.033 \\
\hline Observations & 1,848 & 1,848 \\
\hline
\end{tabular}


Table 3. Demographic and campaign strategy effects on employee charitable gift amount among donors (OLS)

\begin{tabular}{|c|c|c|}
\hline VARIABLES & $\begin{array}{l}\text { Workplace } \\
\text { Giving, Donors } \\
\text { Only, No Donor } \\
\text { Choice Variable } \\
\text { (Log) }\end{array}$ & $\begin{array}{l}\text { Workplace Giving, } \\
\text { Donors Only, With } \\
\text { Donor Choice } \\
\text { Variable (Log) }\end{array}$ \\
\hline \multicolumn{3}{|l|}{ Income [up to $\$ 49,999$ omitted] } \\
\hline$\$ 50,000$ to $\$ 99,999$ & $\begin{array}{l}0.471 * * * \\
(0.137)\end{array}$ & $\begin{array}{l}0.534 * * * \\
(0.147)\end{array}$ \\
\hline$\$ 100,000$ to $\$ 149,999$ & $\begin{array}{l}0.926 * * * \\
(0.159)\end{array}$ & $\begin{array}{l}0.810^{* * *} \\
(0.168)\end{array}$ \\
\hline$\$ 150,000$ to $\$ 174,999$ & $\begin{array}{l}1.021 * * * \\
(0.233)\end{array}$ & $\begin{array}{l}1.133 * * * \\
(0.244)\end{array}$ \\
\hline$\$ 175,000$ and up & $\begin{array}{l}1.325^{* * *} \\
(0.266)\end{array}$ & $\begin{array}{l}1.178^{* * *} \\
(0.283)\end{array}$ \\
\hline Education [Bachelor's or higher] & $\begin{array}{l}0.502 * * * \\
(0.121)\end{array}$ & $\begin{array}{l}0.444 * * * \\
(0.124)\end{array}$ \\
\hline \multicolumn{3}{|l|}{ Age [22-47 omitted] } \\
\hline $48-66$ & $\begin{array}{l}0.232 * * \\
(0.117)\end{array}$ & $\begin{array}{l}0.0927 \\
(0.123)\end{array}$ \\
\hline $67+$ & $\begin{array}{l}-0.148 \\
(0.217)\end{array}$ & $\begin{array}{l}-0.261 \\
(0.220)\end{array}$ \\
\hline Female & $\begin{array}{l}-0.0853 \\
(0.121)\end{array}$ & $\begin{array}{l}-0.151 \\
(0.128)\end{array}$ \\
\hline Donor choice is offered & & $\begin{array}{l}0.717^{* * *} \\
(0.125)\end{array}$ \\
\hline Donor matching is offered & $\begin{array}{l}0.232 * * \\
(0.114)\end{array}$ & $\begin{array}{l}0.121 \\
(0.120)\end{array}$ \\
\hline Public recognition is important & $\begin{array}{l}0.0398 \\
(0.508)\end{array}$ & $\begin{array}{l}-0.00654 \\
(0.539)\end{array}$ \\
\hline $\begin{array}{l}\text { Solicitation support: Employer asking is } \\
\text { a motivator }\end{array}$ & $\begin{array}{l}-0.0546 \\
(0.126)\end{array}$ & $\begin{array}{l}-0.124 \\
(0.131)\end{array}$ \\
\hline $\begin{array}{l}\text { Solicitation support: Friend/Associate } \\
\text { asking is a motivator }\end{array}$ & $\begin{array}{l}-0.250^{*} \\
(0.140)\end{array}$ & $\begin{array}{l}-0.239 \\
(0.149)\end{array}$ \\
\hline Constant & $\begin{array}{l}3.602^{* * *} \\
(0.211)\end{array}$ & $\begin{array}{l}3.310^{* * * *} \\
(0.227)\end{array}$ \\
\hline R-squared & 0.148 & 0.172 \\
\hline Observations & 1,084 & 1,084 \\
\hline
\end{tabular}

Only respondents who gave through the workplace giving and answered all relevant questions included here. Robust standard errors in parentheses

${ }^{* * *} p<0.01,{ }^{* *} p<0.05,{ }^{*} p<0.1$ 


\section{APPENDIX}

Table A. Survey questions and coding strategy

\begin{tabular}{|c|c|c|}
\hline Question & Original Format & Modified Format \\
\hline $\begin{array}{l}\text { Did you have the option to direct all or a } \\
\text { portion of your workplace campaign } \\
\text { donation to a specific nonprofit } \\
\text { organization or cause in the past } 12 \\
\text { months? }\end{array}$ & $\begin{array}{l}\text { Yes }=1 \\
\text { No }=2 \\
\text { Don't know }=3\end{array}$ & $\begin{array}{l}\text { Yes }=1 \\
\text { No }=0 \\
\text { Don't know = missing }\end{array}$ \\
\hline $\begin{array}{l}\text { To your knowledge, what types of } \\
\text { charitable giving is your employer involved } \\
\text { in? } \\
\text { Matching employee donations to } \\
\text { charities }\end{array}$ & $\begin{array}{l}\text { Yes }=1 \\
\text { No }=0\end{array}$ & $\begin{array}{l}\text { Yes }=1 \\
\text { No }=0\end{array}$ \\
\hline $\begin{array}{l}\text { When you make donations to a workplace } \\
\text { campaign, how important is it to you that } \\
\text { the workplace campaign organization } \\
\text { Give public recognition for my } \\
\text { donation }\end{array}$ & $\begin{array}{l}\text { Very Unimportant }=1 \\
\text { Somewhat Unimportant }=2 \\
\text { Neutral/No Opinion }=3 \\
\text { Somewhat Important }=4 \\
\text { Very Important }=5\end{array}$ & $\begin{array}{l}\text { Very Important }=1 \\
\text { Very Unimportant / Somewhat } \\
\text { Unimportant / Neutral / } \\
\text { Somewhat Important = } 0 \\
\text { (Note: Other formats tested for } \\
\text { robustness, no significant } \\
\text { changes) }\end{array}$ \\
\hline $\begin{array}{l}\text { Indicate whether the following is a major } \\
\text { motivation, minor motivation, or no } \\
\text { motivation at all when you give to nonprofit } \\
\text { organizations: } \\
\text { Being asked by your employer } \\
\text { Being asked by a friend or associate }\end{array}$ & $\begin{array}{l}\text { Major Motivation }=1 \\
\text { Minor Motivation }=2 \\
\text { No Motivation at All }=3\end{array}$ & $\begin{array}{l}\text { Major/Minor Motivation }=1 \\
\text { No Motivation at All = } 0 \\
\text { (Note: Other formats tested for } \\
\text { robustness, no significant } \\
\text { changes) }\end{array}$ \\
\hline
\end{tabular}


Table B. Demographic and campaign strategy effects on employee participation in charitable giving and amounts, with industry effects (probit marginal effects; OLS with donors only)

\begin{tabular}{|c|c|c|c|}
\hline VARIABLES & $\begin{array}{l}\text { Nonworkplace } \\
\text { Giving }\end{array}$ & $\begin{array}{l}\text { Workplace } \\
\text { Giving }\end{array}$ & $\begin{array}{l}\text { Workplace } \\
\text { Giving, } \\
\text { Donors } \\
\text { Only (Log) } \\
\end{array}$ \\
\hline \multicolumn{4}{|l|}{ Income [Below $\$ 50,000$ omitted] } \\
\hline$\$ 50,000$ to $\$ 99,999$ & $\begin{array}{l}0.0380 \\
(0.0335)\end{array}$ & $\begin{array}{l}0.0371 \\
(0.0420)\end{array}$ & $\begin{array}{l}0.550^{* * *} \\
(0.148)\end{array}$ \\
\hline$\$ 100,000$ to $\$ 149,999$ & $\begin{array}{l}0.139 * * * \\
(0.0303)\end{array}$ & $\begin{array}{l}0.145^{* * *} \\
(0.0488)\end{array}$ & $\begin{array}{l}0.819 * * * \\
(0.165)\end{array}$ \\
\hline$\$ 150,000$ to $\$ 174,999$ & $\begin{array}{l}0.0874 \\
(0.0570)\end{array}$ & $\begin{array}{l}0.0328 \\
(0.0849)\end{array}$ & $\begin{array}{l}1.156^{* * *} \\
(0.244)\end{array}$ \\
\hline$\$ 175,000$ and up & $\begin{array}{l}0.124^{* *} \\
(0.0501)\end{array}$ & $\begin{array}{l}0.00708 \\
(0.0871)\end{array}$ & $\begin{array}{l}1.197 * * * \\
(0.285)\end{array}$ \\
\hline Education [Bachelor’s or higher] & $\begin{array}{l}0.0596 * * \\
(0.0257)\end{array}$ & $\begin{array}{l}0.0643^{*} \\
(0.0347)\end{array}$ & $\begin{array}{l}0.483 * * * \\
(0.131)\end{array}$ \\
\hline \multicolumn{4}{|l|}{ Age [22-47 omitted] } \\
\hline $48-66$ & $\begin{array}{l}0.0443^{*} \\
(0.0241)\end{array}$ & $\begin{array}{l}0.119 * * * \\
(0.0327)\end{array}$ & $\begin{array}{l}0.0904 \\
(0.126)\end{array}$ \\
\hline $67+$ & -0.00372 & 0.0644 & -0.243 \\
\hline Female & $\begin{array}{l}(0.0769) \\
0.0454^{*} \\
(0.0271)\end{array}$ & $\begin{array}{l}(0.0924) \\
0.00734 \\
(0.0349)\end{array}$ & $\begin{array}{l}(0.222) \\
-0.114 \\
(0.151)\end{array}$ \\
\hline \multicolumn{4}{|l|}{ Industry [Health, Services, \& Recreation omitted] } \\
\hline Finance, Trade, Tech, \& Management & $\begin{array}{l}0.00368 \\
(0.0314)\end{array}$ & $\begin{array}{l}0.0716 * \\
(0.0383)\end{array}$ & $\begin{array}{l}0.0604 \\
(0.147)\end{array}$ \\
\hline Primary \& Secondary Industries & $\begin{array}{l}0.0801 * * \\
(0.0338)\end{array}$ & $\begin{array}{l}0.146 * * * \\
(0.0513)\end{array}$ & $\begin{array}{l}0.212 \\
(0.207)\end{array}$ \\
\hline Donor choice is offered & & & $\begin{array}{l}0.716^{* * * *} \\
(0.122)\end{array}$ \\
\hline Donor matching is offered & $\begin{array}{l}0.0228 \\
(0.0288)\end{array}$ & $\begin{array}{l}0.0458 \\
(0.0367)\end{array}$ & $\begin{array}{l}0.0595 \\
(0.120)\end{array}$ \\
\hline Public recognition is important & $\begin{array}{l}-0.0638 \\
(0.0745)\end{array}$ & $\begin{array}{l}-0.130 \\
(0.0976)\end{array}$ & $\begin{array}{l}0.0247 \\
(0.541)\end{array}$ \\
\hline Solicitation support: Employer asking is a motivator & $\begin{array}{l}-0.0205 \\
(0.0271)\end{array}$ & $\begin{array}{l}0.0868 * * \\
(0.0354)\end{array}$ & $\begin{array}{l}-0.122 \\
(0.134)\end{array}$ \\
\hline $\begin{array}{l}\text { Solicitation support: Friend/Associate asking is a } \\
\text { motivator }\end{array}$ & $\begin{array}{l}0.0338 \\
(0.0251)\end{array}$ & $\begin{array}{l}0.0231 \\
(0.0366)\end{array}$ & $\begin{array}{l}-0.223 \\
(0.149)\end{array}$ \\
\hline Pseudo R-squared & 0.064 & 0.042 & 0.177 \\
\hline Observations & 1,841 & 1,841 & 1,077 \\
\hline
\end{tabular}

In columns $1 \& 2$, all respondents who had workplace giving offered and answered all relevant questions were included. In column 3, only respondents who gave through the workplace giving and answered all relevant questions were included. Coefficients are marginal effects. Robust standard errors in parentheses ${ }^{* * *} p<0.01,{ }^{* *} p<0.05,{ }^{*} p<0.1$ 
Table C. Marginal effects on giving incidence, split by industry (probit marginal effects)

\begin{tabular}{|c|c|c|c|}
\hline VARIABLES & $\begin{array}{l}\text { Workplace } \\
\text { Giving } \\
\text { Health } \\
\text { Services } \\
\text { Rec } \\
\end{array}$ & $\begin{array}{l}\text { Workplace } \\
\text { Giving } \\
\text { Finance, } \\
\text { Trade, Tech, } \\
\text { Management }\end{array}$ & $\begin{array}{c}\text { Workplace } \\
\text { Giving } \\
\text { Primary \& } \\
\text { Secondary } \\
\text { Ind }\end{array}$ \\
\hline \multicolumn{4}{|l|}{ Income [Below $\$ 50,000$ omitted] } \\
\hline$\$ 50,000$ to $\$ 99,999$ & $\begin{array}{c}0.0754 \\
(0.0628)\end{array}$ & $\begin{array}{l}-0.0834 \\
(0.0595)\end{array}$ & $\begin{array}{c}0.0848 \\
(0.0961)\end{array}$ \\
\hline$\$ 100,000$ to $\$ 149,999$ & $\begin{array}{l}0.191^{* *} \\
(0.0797)\end{array}$ & $\begin{array}{c}0.0519 \\
(0.0682)\end{array}$ & $\begin{array}{l}0.0973 \\
(0.107)\end{array}$ \\
\hline$\$ 150,000$ to $\$ 174,999$ & $\begin{array}{l}0.0913 \\
(0.124)\end{array}$ & $\begin{array}{c}-0.0913 \\
(0.114)\end{array}$ & $\begin{array}{c}0.163 \\
(0.131)\end{array}$ \\
\hline$\$ 175,000$ and up & $\begin{array}{c}0.166 \\
(0.129)\end{array}$ & $\begin{array}{l}-0.00105 \\
(0.0933)\end{array}$ & $\begin{array}{l}-0.310^{*} \\
(0.172)\end{array}$ \\
\hline Education [Bachelor’s or higher] & $\begin{array}{l}0.110^{* *} \\
(0.0546)\end{array}$ & $\begin{array}{c}-0.0181 \\
(0.0511)\end{array}$ & $\begin{array}{c}0.0711 \\
(0.0647)\end{array}$ \\
\hline \multicolumn{4}{|l|}{ Age [22-47 omitted] } \\
\hline $48-66$ & $\begin{array}{c}0.153^{* * *} \\
(0.0530)\end{array}$ & $\begin{array}{c}0.0941 * * \\
(0.0432)\end{array}$ & $\begin{array}{c}0.0588 \\
(0.0696)\end{array}$ \\
\hline $67+$ & $\begin{array}{c}-0.0100 \\
(0.137)\end{array}$ & $\begin{array}{c}0.170^{*} \\
(0.0980)\end{array}$ & $\begin{array}{c}0.110 \\
(0.195)\end{array}$ \\
\hline Female & $\begin{array}{c}-0.00226 \\
(0.0547)\end{array}$ & $\begin{array}{l}-0.0102 \\
(0.0500)\end{array}$ & $\begin{array}{c}0.0565 \\
(0.0756)\end{array}$ \\
\hline Donor matching is offered & $\begin{array}{l}-0.0845 \\
(0.0619)\end{array}$ & $\begin{array}{l}0.111^{* *} \\
(0.0481)\end{array}$ & $\begin{array}{c}0.174 * * * \\
(0.0672)\end{array}$ \\
\hline Public recognition is important & $\begin{array}{l}-0.167 \\
(0.133)\end{array}$ & $\begin{array}{c}-0.0409 \\
(0.144)\end{array}$ & $\begin{array}{c}-0.134 \\
(0.162)\end{array}$ \\
\hline $\begin{array}{l}\text { Solicitation support: Employer asking is a } \\
\text { motivator }\end{array}$ & $\begin{array}{c}0.107 * \\
(0.0555)\end{array}$ & $\begin{array}{c}0.0488 \\
(0.0505)\end{array}$ & $\begin{array}{l}0.142 * * \\
(0.0720)\end{array}$ \\
\hline $\begin{array}{l}\text { Solicitation support: Friend/Associate asking is a } \\
\text { motivator }\end{array}$ & $\begin{array}{c}0.0464 \\
(0.0585)\end{array}$ & $\begin{array}{c}0.0579 \\
(0.0536)\end{array}$ & $\begin{array}{l}-0.0579 \\
(0.0726)\end{array}$ \\
\hline Observations & 751 & 781 & 309 \\
\hline
\end{tabular}

All respondents who had workplace giving offered and answered all relevant questions included here. Columns split by industry classification.

Robust see form in parentheses

*** $p<0.01,{ }^{* *} p<0.05,{ }^{*} p<0.1$ 
Table D. Effects on giving campaign characteristics (probit marginal effects)

\begin{tabular}{|c|c|c|c|}
\hline VARIABLES & $\begin{array}{c}\text { Workplace } \\
\text { Giving Offered }\end{array}$ & $\begin{array}{c}\text { Donor Matching } \\
\text { Offered }\end{array}$ & $\begin{array}{c}\text { Donor Choice } \\
\text { Offered }\end{array}$ \\
\hline \multicolumn{4}{|l|}{ Income [Below $\$ 50,000$ omitted] } \\
\hline$\$ 50 \mathrm{k}-\$ 99 \mathrm{k}$ & $\begin{array}{c}0.0895^{* * *} \\
(0.0237)\end{array}$ & $\begin{array}{c}0.0393 \\
(0.0338)\end{array}$ & $\begin{array}{l}0.00881 \\
(0.0375)\end{array}$ \\
\hline$\$ 100 \mathrm{k}-\$ 150 \mathrm{k}$ & $\begin{array}{c}0.0933^{* * *} \\
(0.0308)\end{array}$ & $\begin{array}{l}0.0911^{* *} \\
(0.0392)\end{array}$ & $\begin{array}{c}0.0621 \\
(0.0401)\end{array}$ \\
\hline$\$ 150 \mathrm{k}-\$ 175 \mathrm{k}$ & $\begin{array}{c}0.0748 \\
(0.0479)\end{array}$ & $\begin{array}{l}0.212^{* * *} \\
(0.0656)\end{array}$ & $\begin{array}{c}0.0178 \\
(0.0826)\end{array}$ \\
\hline$\$ 175 \mathrm{k}+$ & $\begin{array}{c}0.0567 \\
(0.0459)\end{array}$ & $\begin{array}{l}0.175^{* * *} \\
(0.0585)\end{array}$ & $\begin{array}{c}0.0420 \\
(0.0584)\end{array}$ \\
\hline \multicolumn{4}{|l|}{ Education (less than college omitted) } \\
\hline Bachelor's or higher & $\begin{array}{l}0.125^{* * *} \\
(0.0210)\end{array}$ & $\begin{array}{l}-0.00686 \\
(0.0283)\end{array}$ & $\begin{array}{l}0.00429 \\
(0.0307)\end{array}$ \\
\hline \multicolumn{4}{|l|}{ Age $[22-47$ omitted] } \\
\hline $48-66$ & $\begin{array}{l}0.00708 \\
(0.0205)\end{array}$ & $\begin{array}{l}-0.0425 \\
(0.0267)\end{array}$ & $\begin{array}{l}0.0618^{* *} \\
(0.0289)\end{array}$ \\
\hline $67+$ & $\begin{array}{l}-0.213^{* * *} \\
(0.0572)\end{array}$ & $\begin{array}{c}0.0357 \\
(0.0815)\end{array}$ & $\begin{array}{c}0.0634 \\
(0.0707)\end{array}$ \\
\hline Female & $\begin{array}{l}0.0377^{*} \\
(0.0207)\end{array}$ & $\begin{array}{c}0.0117 \\
(0.0279)\end{array}$ & $\begin{array}{l}-0.0595^{*} \\
(0.0308)\end{array}$ \\
\hline \multicolumn{4}{|l|}{ Industry [Health, Services, \& } \\
\hline Finance, Trade, Tech, \& Management & $\begin{array}{l}-0.0294 \\
(0.0221)\end{array}$ & $\begin{array}{l}0.244^{* * *} \\
(0.0284)\end{array}$ & $\begin{array}{c}-0.0671^{* *} \\
(0.0322)\end{array}$ \\
\hline Primary \& Secondary Industries & $\begin{array}{c}-0.0933^{* * *} \\
(0.0308)\end{array}$ & $\begin{array}{l}0.314^{* * *} \\
(0.0443)\end{array}$ & $\begin{array}{l}-0.0103 \\
(0.0458)\end{array}$ \\
\hline Observations & 5,764 & 2,801 & 1,764 \\
\hline
\end{tabular}

All respondents who had workplace giving offered and answered all relevant questions included here. Robust standard errors in parentheses.

${ }^{* * *} p<0.01,{ }^{* *} p<0.05,{ }^{*} p<0.1$ 